\title{
Watermelon Seeds as Food: Nutrient Composition, Phytochemicals and Antioxidant Activity
}

\author{
Betty Tabiri, Jacob K. Agbenorhevi", Faustina D. Wireko-Manu, Elsa I. Ompouma \\ Department of Food Science and Technology, Kwame Nkrumah University of Science and Technology, Kumasi, Ghana
}

Email address:

jkagbenorhevi@yahoo.com (J. K. Agbenorhevi),jkagbenorhevi.cos@knust.edu.gh (J. K. Agbenorhevi)

${ }^{*}$ Corresponding author

\section{To cite this article:}

Betty Tabiri, Jacob K. Agbenorhevi, Faustina D. Wireko-Manu, Elsa I. Ompouma. Watermelon Seeds as Food: Nutrient Composition, Phytochemicals and Antioxidant Activity. International Journal of Nutrition and Food Sciences. Vol. 5, No. 2, 2016 pp. $139-144$. doi: $10.11648 /$ j.ijnfs.20160502.18

Received: March 7, 2016; Accepted: March 18, 2016; Published: March 30, 2016

\begin{abstract}
Watermelon (Citrullus lanatus) seeds are often discarded while the fruit is eaten. In this study, seeds of three (3) varieties of watermelon (Charleston gray, Crimson sweet and Black diamond) were analyzed for their proximate, minerals, phytochemicals, total phenols content and antioxidant activity. The proximate analysis and phytochemicals screening were performed using standard procedures whereas minerals content was determined by atomic absorption spectrophotometry. DPPH free radical scavenging activity and Folin-ciocalteau assays were used to determine antioxidant activity and total phenol content, respectively. The results indicated that the watermelon seeds had moisture content in the range of $7.40-8.50 \%$; fat, 26.50 27.83\%; protein, $16.33-17.75 \%$; fibre, $39.09-43.28 \%$; ash, $2.00-3.00 \%$; carbohydrate, $9.55-15.32 \%$ and energy value of $354.05-369.11 \mathrm{kcal} / 100 \mathrm{~g}$. The seeds also contained appreciable minerals (Ca, $\mathrm{P}, \mathrm{Mg}, \mathrm{Na}, \mathrm{K}$ and $\mathrm{Zn})$ with $\mathrm{K}(3.40-3.5 \mathrm{mg} / 100 \mathrm{~g})$ being the highest while $\mathrm{Na}(0.07-0.08 \mathrm{mg} / 100 \mathrm{~g})$ was the least. DPPH\% inhibition varied between $59.88-94.46 \%$ inhibition with trolox equivalent of 82.59-130.29 $\mu \mathrm{M} / \mathrm{g}$ depending on the variety. Saponins, tannins, triterpenoids glycosides and alkaloids were present in all samples. Crimson sweet seeds had the highest total phenol content (5416 mgGAE/100g), followed by Black diamond (3949 mg GAE/100g) and the least, Charleston gray (1494 mg GAE/100g). Similarly, Crimson sweet had the highest antioxidant activity, followed by Black diamond and lastly, Charleston gray. The present findings suggest watermelon seeds as considerable source of nutrients in the diet and may have health and economic benefits due to its fibre, minerals, phenolics content and antioxidant activity.
\end{abstract}

Keywords: Citrullus lanatus, Proximate Composition, Minerals, Total Phenols, Free Radical Scavenging Activity

\section{Introduction}

Watermelon (Citrullus lanatus) a fruit crop, is a herbaceous creeping plant belonging to the family cucurbitaceae. It is mainly propagated by seeds and thrives best in warm areas. It is a tropical plant and requires a lot of sunshine and high temperature of over $25^{\circ} \mathrm{C}$ for optimum growth. Watermelon thrives best in a drained fertile soil of fairly acidic nature. It can be grown along the coastal areas of Ghana, the forest zone and especially along river beds in the Northern Savannah areas [1]

The sugar content and sweetness are the critical factors in determining the quality of many watermelon varieties. It is known to be low in calories but highly nutritious and thirst quenching. Watermelon can be used as fresh salad, dessert, snack, and for decorations. Drinks can also be made from the juice. In Namibia, the juice is fermented into a refreshing, lightly alcoholic drink [2]. In some parts of Africa, the rind is sliced, dried, cooked and eaten. Pickled watermelon rind is widely eaten in some parts of USA. The fruit is known to be a good source of lycopene and carotenoid. It helps quench the free radicals that contribute to conditions like asthma, atherosclerosis, diabetes, colon cancer and arthritis. It is also high in fibre and citrulline; an amino acid the body uses to make arginine [3].

Watermelon seeds are known to be highly nutritional; they are rich sources of protein, vitamins B, minerals (such as magnesium, potassium, phosphorous, sodium, iron, zinc, manganese and copper) and fat among others as well as 
phytochemicals [4]. The seeds of watermelons are known to have economic benefits especially in countries where cultivation is on the increase. The seeds are for instance used to prepare snacks, milled into flour and used for sauces. Oil from the seeds are used in cooking and incorporated into the production of cosmetics [5]. In spite of the various potential applications, the watermelon seeds are often discarded while the fruit is eaten. There is also limited literature on the effect of variety on the nutritional, phytochemical and antioxidant properties of the watermelon seeds. In this study, the proximate and antioxidant activity were determined in the seeds of three of watermelon varieties. The seeds were also screened for the presence of some phytochemicals and minerals content.

\section{Materials and Methods}

\subsection{Materials and Sample Preparation}

Folin-Ciocalteu phenol reagent $(2 \mathrm{~N})$, Trolox $\left(\mathrm{C}_{14} \mathrm{H}_{18} \mathrm{O}_{4}\right.$, $97 \%)$ Gallic acid $\left(\mathrm{C}_{6} \mathrm{H}_{2}\left(\mathrm{OH}_{3}\right) \mathrm{COOH}\right)$ and 2,2-diphenyl-1-picryhydrazyl (DPPH radical) were purchased from Sigma-Aldrich (Poole, Dorset, UK). All other chemicals used were of analytical grade.

The watermelon fruits were purchased from the Bantaman fruit Market, Ashanti Region, Ghana. The seeds from the three varieties of watermelon namely; Charleston gray, Crimson sweet and Black diamond were removed from the fruits, washed and dried. The dried seeds were milled with a mechanical blender and stored in the refrigerator for further analysis.

\subsection{Determination of Proximate Composition}

Proximate analysis: crude moisture, crude fat, crude protein, crude ash, crude fibre, carbohydrates and energy determination and the minerals content were done using the AOAC (2005) methodology. The percentage nitrogen was determined by the macro-Kjeldahl method and converted to crude protein content by multiplying with factor 6.25 . Carbohydrate content was determined by difference.

\subsection{Determination of Minerals}

The cations ( $\mathrm{Ca}, \mathrm{Mg}, \mathrm{K}, \mathrm{Na}, \mathrm{Zn}, \mathrm{Cu}, \mathrm{Mn}$ and $\mathrm{Fe}$ ) were determined using flame atomic absorption spectrophotometer (model VGP 210, Buck Scientific, USA).

\subsection{Phytochemicals Screening}

The samples were screened for phytochemicals (flavonoids, cyanogenic and anthracene glycosides, saponins, tannins, triterpenoids glycosides and alkaloids) according to the procedure as described elsewhere $[6,7,8]$.

\subsection{Determinations of Antioxidant Activity}

The antioxidant activity was determined by means of DPPH radical scavenging assay [8, 9].

To $0.2 \mathrm{~mL}$ of each extracted sample and the standard Trolox solutions, $3.8 \mathrm{~mL}$ of $0.1 \mathrm{mM}$ DPPH solution was added in a test tube. The mixtures were shaken for 1 minute and then left in the dark for 30 minutes after which the absorbance was read using spectrophotometer at $517 \mathrm{~nm}$ against the blank. Absorbance of a negative control $\left(\mathrm{A}_{\text {control }}\right)$ was taken after adding DPPH radical solution to $0.2 \mathrm{~mL}$ of the extraction solvent (distilled water).

$$
\% \text { DPPH radical inhibition }=\frac{\text { Acontrol }- \text { Asample } \times 100}{\text { Acontrol }}
$$

From equation 1, the free radical scavenging (antioxidant) activity was expressed as the mean micromole of Trolox equivalent $(\mu \mathrm{MTE} / \mathrm{g})$.

\subsection{Determinations of Total Phenol Content}

The total phenol content was analysed using Folin-Ciocalteu method as previously reported [9, 10]. For each standard gallic acid solutions and samples as well as the blank (distilled water), $0.1 \mathrm{~mL}$ was pipetted into a $10 \mathrm{~mL}$ volumetric flask and $6.0 \mathrm{~mL}$ of distilled water added. This was followed by the addition of $0.5 \mathrm{~mL}$ of Folin-Ciocalteu reagent $(2 \mathrm{~N})$. Each sample was well mixed and then left for 5 minutes after which $1.5 \mathrm{~mL}$ of $20 \%$ sodium carbonate solution was added. The solution was made up to the $10 \mathrm{~mL}$ mark with distilled water and mixed thoroughly. The resulting solution was then incubated at $20-23^{\circ} \mathrm{C}$ for 2 hours under the dark after which absorbance readings were taken at $765 \mathrm{~nm}$ using Shimazu UV-VIS 160 A spectrophotometer. Triplicate absorbance readings were taken for each of the duplicate determinations for each sample. The results for the samples were expressed as concentration of gallic acid equivalent (mg $\mathrm{GAE} / 100 \mathrm{~g}$ ) using the equation obtained from the standard calibration curve.

\subsection{Statistical Analysis}

Statistical significance tests were performed using SPSS (v.20, IBM SPSS Statistics, US) at $p<0.05$ by means of one-way analysis of variance (ANOVA) followed by LSD post hoc multiple comparisons.

\section{Results and Discussion}

Table 1. Proximate composition of seeds of three watermelon varieties.

\begin{tabular}{|c|c|c|c|c|c|c|c|}
\hline Watermelon variety & $\%$ Moisture & $\%$ Protein & $\%$ Fat & $\%$ Ash & $\%$ Fibre & $\%$ Carbohydrate & Energy (kcal/100g) \\
\hline Charleston gray & $7.87 \pm 0.12^{\mathrm{b}}$ & $17.75 \pm 0.97^{\mathrm{a}}$ & $26.83 \pm 4.24^{\mathrm{a}}$ & $3.00 \pm 1.00^{\mathrm{a}}$ & $40.75 \pm 6.12^{\mathrm{a}}$ & $11.67 \pm 6.62^{\mathrm{a}}$ & $359.15 \pm 34.19^{\mathrm{a}}$ \\
\hline Crimson Sweet & $7.40 \pm 0.00^{c}$ & $17.09 \pm 0.92^{\mathrm{a}}$ & $26.50 \pm 4.27^{\mathrm{a}}$ & $2.00 \pm 1.00^{\mathrm{a}}$ & $39.09 \pm 0.50^{\mathrm{a}}$ & $15.32 \pm 4.51^{\mathrm{a}}$ & $368.11 \pm 19.91^{\mathrm{a}}$ \\
\hline Black diamond & $8.00 \pm 0.00^{\mathrm{a}}$ & $16.33 \pm 0.97^{\mathrm{a}}$ & $27.83 \pm 2.63^{\mathrm{a}}$ & $3.00 \pm 0.00^{\mathrm{a}}$ & $43.28 \pm 3.44^{\mathrm{a}}$ & $9.56 \pm 4.65^{\mathrm{a}}$ & $354.05 \pm 10.14^{\mathrm{a}}$ \\
\hline
\end{tabular}

Values are reported as mean \pm SD. Values with same letters in rows are not significantly different $(p>0.05)$. 
Table 2. Mineral Composition of seeds of three watermelon varieties.

\begin{tabular}{|c|c|c|c|c|c|c|c|c|c|}
\hline Wat & $\% \mathrm{P}$ & $\% \mathrm{Ca}$ & $\%$ Mn & $\% \mathrm{~K}$ & $\% \mathrm{Na}$ & $\% \mathrm{Mg}$ & 00g) & g/100g) & 1g/100g) \\
\hline Charleston gray & $0.17 \pm 0.00^{\mathrm{a}}$ & $0.16 \pm 0.02^{\mathrm{a}}$ & $0.02 \pm 0.00^{\mathrm{b}}$ & $3.57 \pm 0.14^{b}$ & $0.07 \pm 0.01^{\mathrm{a}}$ & $0.15 \pm 0.01^{\mathrm{a}}$ & $3.71 \pm 0.06^{\mathrm{c}}$ & $0.38 \pm 0.06^{\mathrm{b}}$ & $3.71 \pm 0.06^{\mathrm{b}}$ \\
\hline Crimson Sweet & $0.22 \pm 0.03^{\mathrm{a}}$ & $0.11 \pm 0.01^{\mathrm{a}}$ & $0.04 \pm 0.00^{c}$ & $3.40 \pm 0.07^{\mathrm{b}}$ & $0.08 \pm 0.00^{\mathrm{a}}$ & $0.14 \pm 0.02^{\mathrm{a}}$ & $2.72 \pm 0.11^{\mathrm{b}}$ & $0.45 \pm 0.24^{\mathrm{b}}$ & $0.81 \pm 0.02^{\mathrm{a}}$ \\
\hline Black diamond & $0.18 \pm 0.02^{\mathrm{a}}$ & $0.14 \pm 0.03^{\mathrm{a}}$ & $0.09 \pm 0.01^{\mathrm{a}}$ & $3.85 \pm 0.11^{\mathrm{a}}$ & $0.17 \pm 0.02^{\mathrm{a}}$ & $0.17 \pm 0.02^{\mathrm{a}}$ & $4.60 \pm 0.07^{\mathrm{a}}$ & $0.58 \pm 0.03^{\mathrm{a}}$ & $0.66 \pm 0.03^{c}$ \\
\hline
\end{tabular}

Values are reported as mean \pm SD. Values with different superscript letters are significantly different $(p<0.05)$.

Table 3. Total Phenol content and antioxidant activity of seeds of three watermelon varieties.

\begin{tabular}{llll}
\hline Variety & Total Phenol (mg GAE/100g) & \% DPPH Inhibition & Trolox equivalent $(\boldsymbol{\mu M T E} / \mathbf{g})$ \\
\hline Charleston gray & $1494 \pm 19.99^{\mathrm{a}}$ & $59.88 \pm 0.62^{\mathrm{a}}$ & $82.59^{\mathrm{a}}$ \\
Crimson sweet & $5416 \pm 27.99^{\mathrm{b}}$ & $94.66 \pm 0.55^{\mathrm{b}}$ & $130.29^{\mathrm{b}}$ \\
Black diamond & $3949 \pm 89.71^{\mathrm{c}}$ & $70.06 \pm 0.56^{\mathrm{c}}$ & $96.63^{\mathrm{c}}$ \\
\hline
\end{tabular}

Values are reported as mean \pm SD. Values with different superscript letters are significantly different $(p<0.05)$.

The results of the proximate and minerals composition of the watermelon seeds studied are presented in Table $1 \& 2$, respectively whereas those of total phenols content and antioxidant activity are shown in Table 3.

Available literature on composition of watermelon seeds showed different percentages of protein, fat, fibre, moisture, ash and carbohydrate contents in comparison to the present results [11]. The possible reason for such a difference could be attributed to varietal and regional/soil differences.

In this study, the highest record among the proximate parameters analyzed was found with crude fibre, which was 43.28\%, 40.75\% and 39.09\%, respectively for Black Diamond, Charleston Gray and Crimson Sweet. There was no significant difference $(\mathrm{p}<0.05)$ among the three varieties. These values are much higher compared to $6.46 \%$ and $6.56 \%$ respectively for cotton seeds and sunflower seeds as reported by FAO (1982) [12]. Again, the crude fibre value of these varieties was found to be higher than that of pumpkin seeds [12]. The fibre in foods is known to expand the inside walls of the colon, easing the passage of waste, thus making it effective against constipation; it lowers cholesterol level in the blood and reduce the risk of various cancers.

The crude fat (oil content of the seed) extracted had the second higher amount in the proximate composition of the samples. These values were $27.83 \%, 26.83 \%$ and $26.50 \%$ for Black Diamond, Charleston Gray and Crimson Sweet, respectively. These results also showed no significant difference $(\mathrm{p}<0.05)$ among the three varieties. It is important to note that watermelon seeds could be exploited for oil production. The findings of this study could be exploited further to know the variety that might produce more oil as edible oil. Mabalaha et al., (2007) [15] also reported oil yields of seeds ranging from $24.8-30.0 \%$ in Citrillus lanatus and $C$. colocynth species respectively, whereas Madaan and Lai (1984) [13] reported oil content values of 41.0-56.6\% in melon seeds. The percentage of fat extracted reported by Oyeleke et al. (2012) [3] was 47.9\% from watermelon seeds which is higher than the results obtained from the three varieties of watermelon in this study. That of Lakshmi and Kaul (2011) [11] also showed a fat content of $46.83 \%$ for the seed meal. Oil provides concentrated energy in diet and enhanced palatability. It is worthy to note that major edible oils are from palm oil and peanut which are capital and labour intensive and therefore there is need to source for good, cheap and novel source of oils that would be useful domestically and perhaps industrially. Cucurbit seeds are source of particularly protein and oil $[16,19]$.

The crude protein content showed values of $16.33 \%$, $17.75 \%$ and $17.09 \%$ respectively for Black Diamond, Charleston Gray and Crimson Sweet. There was no significant difference $(p>0.05)$ among the three varieties. The protein contents, were also similar to those of sesame seed, caper, cactus, carob seeds, almond and cereals [21].

Citrullus vulgaris is a member of the cucurbitaceae or the cucurbit family, commonly referred to as the gourd, melon, cucumber or pumpkin. Apart from their potential as a source of protein, melon seeds generally are reported to contain approximately $35 \%$ protein by weight of decorticated seeds that have a nutritionally adequate amino acid profile [18]. The production of food protein in sufficient amounts possesses many problems especially since they are more expensive to produce than carbohydrate or lipids. In order to satisfy this steady growing demand for protein, new protein sources must be explored Wilcox (2006) [19]. Previous works on varieties of $C$. vulgaris seed have shown that it has high protein value that makes the seed valuable as a good source of protein. It contains lipid, carbohydrate and minerals, making it a complete food [20].

The moisture content was $8.00 \%$ for Black Diamond which had the highest amount of water; $7.87 \%$ for Charleston Gray and $7.40 \%$ being the lowest for crimson Sweet. There was significant difference $(\mathrm{p}<0.05)$ among the three varieties. The moisture contents obtained in this study were found to be lower as compared to $6.46 \%$ and $6.56 \%$ reported for cottonseeds and sunflower seeds [12].

The carbohydrate content were 9.55\%, 11.66\% and 15.32\% respectively for Black Diamond, Charleston Gray and Crimson Sweet. There was no significant difference $(\mathrm{p}<0.05)$ among the three varieties. The carbohydrate content obtained from the different varieties were also lower as compared to $26 \%$ reported for sunflower [12]. Other reports of carbohydrate content ranged from $7.08-14.15 \%$. The highest value was in Cucumeropsis edulis while the least was in Leganariasi ceraria. These values were within the range of values recorded for $C$. 
lanatus (9.87\%), C. manni (13.86\%) and C. melo (23.18\%) by Loukou et al., (2007) [14].

The ash percentages of the samples indicate the total inorganic content of the samples from where the mineral content could be obtained. The ash content was $3.00 \%$ for Black Diamond, $3.00 \%$ for Charleston Gray and $2.00 \%$ for Crimson Sweet with no significant difference $(\mathrm{p}<0.05)$ among the three varieties. Sample with high ash content is expected to have high concentration of various mineral elements, which are expected to speed up metabolic processes, improve growth and development.

The mineral content of the various watermelon seeds are presented in Table 2. The results of sodium and phosphorus showed no significant difference $(p>0.05)$ among the three varieties. However, for calcium, manganese, iron and zinc, there were significant differences among the three varieties $(\mathrm{p}<0.05)$. According to Acar et al. (2012) [21] the mineral content of similar samples were found to be different depending on whether seeds are de-hulled or not. The results obtained for the copper in our study (Table 2) were slightly higher as compared to those of Acar et al. (2012) [21]. Concerning iron, Black Diamond, Charleston Gray and Crimson Sweet recorded $4.60 \mathrm{mg} / 100 \mathrm{~g}, 3.71 \mathrm{mg} / 100 \mathrm{~g}$ and $2.72 \mathrm{mg} / 100 \mathrm{~g}$ respectively. These values also were higher than those reported for hulled seed and kernel. In addition, $\mathrm{Zn}$ levels ranged between $3.369 \mathrm{mg} / 100 \mathrm{~g}$ (watermelon hulled seed) to $7.758 \mathrm{mg} / 100 \mathrm{~g}$ (forage watermelon kernel). From the analysis conducted, Black Diamond had $0.66 \mathrm{mg} / 100 \mathrm{~g}$ of $\mathrm{Zn}$, Charleston Gray had $0.78 \mathrm{mg} / 100 \mathrm{~g}$ and Crimson Sweet had $0.81 \mathrm{mg} / 100 \mathrm{~g}$. The values of the zinc were lower than those previously reported [21]. There was $3.85 \%$ of potassium for Black Diamond, 3.57\% for Charleston Gray and 3.40\% for Crimson Sweet. The results show that the different watermelon seeds studied are rich in mineral and could aid in digestion, formation of strong bones and teeth as well as hemoglobin formation. The variation in mineral composition could be due to the climate, species, soil type, water and the cultural practices adopted during planting.

The value of sodium was also higher than in egusi melon (13.0 $\mathrm{mg} / 100 \mathrm{~g})$ [20] and some legume seeds like bambara nuts $(0.05$ $\mathrm{mg} / 100 \mathrm{~g})$, Jack bean $(0.07 \mathrm{mg} / 100 \mathrm{~g})$ pigeon pea $(0.05 \mathrm{mg} / 100$ g). Meanwhile, Black Diamond, Charleston Gray and Crimson Sweet showed $0.08 \%, 0.07 \%$ and $0.08 \%$ respectively. Calcium is an important mineral required for bone formation and neurological function of the body. The calcium content ranged from $0.11-0.16 \mathrm{mg} / 100 \mathrm{~g}$ for the three seed samples. Black Diamond had iron content of $4.6 \mathrm{mg} / 100 \mathrm{~g}$ whiles Charleston Gray and Crimson Sweet had $3.71 \mathrm{mg} / 100 \mathrm{~g}$ and $2.72 \mathrm{mg} / 100 \mathrm{~g}$, respectively. The recommended dietary allowance for iron in adult and children is $10 \mathrm{mg} /$ day while female adult is $15 \mathrm{mg} /$ day. Iron is required for blood haem formation. The seeds studied could therefore contribute to iron needs of consumers. The copper content of Charleston Gray and Crimson Sweet were close to those reported for egusi melon $(0.4 \mathrm{mg} / 100 \mathrm{~g})$ [20]. Copper is a mineral that facilitates the absorption of iron and is also required in the body for enzyme production, biological electron transfer and needed for melanin production. Magnesium is also very important in calcium metabolism in bones and also involved in prevention of circulatory diseases. It helps in regulating blood pressure and insulin release. The manganese values of Black Diamond was $0.09 \mathrm{mg} / 100 \mathrm{~g}$, Charleston Gray had $0.02 \mathrm{mg} / 100 \mathrm{~g}$ and Crimson Sweet was $0.04 \mathrm{mg} / 100 \mathrm{~g}$. The required daily intake of manganese is $2.5 \mathrm{mg}$ [22]. The zinc content of the watermelon seeds ranged from $0.66-0.81 \mathrm{mg} / 100$ $\mathrm{g}$ (Table 2). Zinc is important in diet for many protein and enzymes e.g. haemoglobin to prevent anaemia [22]. WHO recommend $\mathrm{Zn}$ intake of 15 and $10 \mathrm{mg} /$ day, respectively for adult and children. There were differences in the values obtained for the minerals in the present study as compared to Samia et al., (2012) [23] who investigated the mineral content of different seed flours including papaya seed, apple seed, guava seed, watermelon, orange seed prickly pear seed, apricot seed, and paprika seed flour.

Phytochemicals

The screening of the seeds showed the presence of saponins, tannins, triterpenoids, glycosides as well as alkaloids whilst flavonoids, anthracene glycosides and cyanogenic glycosides were absent. Tannins which is a major plant polyphenol when isolated from edible or non-edible plants have shown strong biological activity in the form of anti-tumour, anti-mutagenic, anti-diabetic, anti-proliferative, anti-bacteria and anti-mycotic properties [24]. The treatment of sore throat, haemorrhage and wound healing has also been linked to tannins [25]. But if ingested in excessive quantities, tannins inhibit the absorption of minerals such as iron and calcium which may lead to aneamia or osteoporosis if prolonged [26]. Glycosides which were also present in the seeds are known to have anti-diarrhoeal [27]. Alkaloids are known to be ranked the most efficient therapeutically important plant secondary metabolite and are widely used worldwide as a basic agent for analgestic, antisplasmodic and bacterial effects [28]. Alkaloids were present in all the samples. Oseni et al., (2013) [28] reported that alkaloids were found to have the highest concentration in the seeds.

Cyanogenic glycosides which were absent in all 3 samples are known to be toxic. Cyanogenic glycosides when enzymatically hydrolysed, release cyanohydric acids known as prussic acid. This acid is extremely toxic due to its ability of linking with metals such as $\mathrm{Fe}^{2+}, \mathrm{Mn}^{2+}$ and $\mathrm{Cu}^{2+}$ which are functional groups of many enzymes thereby inhibiting processes like reduction of oxygen in the cytochrome respiratory chain, electron transport in the photosynthesis, and the activity of enzymes like catalase, oxidase [29]. Therefore its absence is preferred. Braide et al., (2012) [4] reported the presence of cyonogenic glycosides in the seeds of watermelon but at a very low percentage of 0.0023 . They observed the presence of saponins, alkaloids, flavonoids, oxalate and tannins in the seeds.

Similar results were observed by Johnson et al. (2012) [30]. with the presence of saponins, alkaloids, tannis, and phytates and absence of flavonoids and oxalate in watermelon seeds. Comparing the results to literature, similar results were observed with the exception of cyanogenic glycosides and flavonoids which were recorded to be present in the seeds as 
reported by Braide et al., (2012) [4]. This could be as a result of the variety and where it was grown. Triterpenoids were also present in all the samples and are known to help heal wounds faster. Oseni and Okoye, (2013) [28], reported the presence of saponins, flavonoids, triterpenes and alkaloids in the seeds of watermelon although the variety was not stated.

\section{Total Phenol Content}

The results showed a considerable amount of phenols in each sample. The seeds from the Crimson sweet variety contained the highest amount of phenols with a value of 5416 mgGAE/100g, followed by Black diamond (3949 mgGAE/100 g) and finally Charleston gray with a total phenol content of $1494 \mathrm{mgGAE} / 100 \mathrm{~g}$. The values for the total phenol content of all three samples differ significantly at $\mathrm{p}<0.05$. From the results in Table 3, it can be observed that feeding on a $100 \mathrm{~g}$ of Crimson sweet seeds may give $5416 \mathrm{mg}$ of total phenols, $3949 \mathrm{mg}$ from Black diamond and 1494mg from seeds of Charleston gray variety. The presences of phenols in fruits and vegetables have attracted attention over the years due to its antioxidant activity. It has the ability to scavenge free radicals and neutralise it effects thereby preventing diseases like cancer and cardiovascular diseases. Literature references also have reported appreciable amount of total phenols in seeds of fruits. Joshi and Jain (2012) [31] reported $969.3 \mathrm{mgGAE} / 100 \mathrm{~g}$ of phenols in watermelon seeds as compared to other fruit seeds like lemon, grape fruit and apple with total phenol content of 158.8, 205.5 and $702 \mathrm{mgGAE} / 100$ g, respectively. Rhaman et al., (2013) [22] and Duda-Chodak and Tarko (2007) [33] also recorded $42.34 \mathrm{mg} / \mathrm{g}$ GAE and $969.3 \mathrm{mg}$ catechin/100 $\mathrm{g} \mathrm{d}$.w. of total phenols in watermelon seeds. Comparing the results to literature, similar results were observed in all three varieties. The slight differences in the results of the total phenols content from literature may be as a result of the differences in the varieties, growing conditions and also the extraction solvent used [32]. In their work it was concluded that watermelon seeds possessed antioxidant activity but the potency depended on the extraction solvent used in the extraction process.

It is well known that there is a strong relationship between total phenol content and antioxidant activity, as phenols possess strong scavenging ability for free radicals due to their hydroxyl groups. Therefore, the phenolic content of plants may directly contribute to their antioxidant action [34].

Antioxidant activity

The antioxidant activity expressed as \% DPPH inhibition of each of the sample is presented in Table 3. From the results, seeds from Crimson variety showed the highest percentage DPPH scavenging ability with 94.46 . This was followed by Black diamond with $70.06 \%$ scavenging ability and finally Charleston gray with $59.88 \%$.

Amongst the three varieties, Crimson sweet showed the highest antioxidant activity and also showed a high phenolic content. The difference of activity may be due to presence of phenolic components in the different extracts since phenols are known to possess high antioxidant activity as compared to other phytochemicals [32].

Oseni and Okoye, (2013) [28] reported 56.93\% DPPH free radical scavenging ability of watermelon seeds. This was similar to the percentage free radical scavenging ability of the seeds of the Charleston gray variety. Acar et al., (2012) [21]. also reported a lower percentage radical scavenging ability of dehulled watermelon seeds with a range of $1.31-13.90 \%$. The antioxidant activity of all 3 samples differed significantly at $p$ $<0.05$. Antioxidants are known to quench free radicals, thus are essential components of anti-ageing formulations. Antioxidants also offer protection against damage to tissues due to the detrimental effects of environmental and other agents and encourage collagen growth by combating harmful effects of free radicals [35]. Consumption of the seeds may reduce the chances of getting cardiovascular diseases and cancers due to the appreciable amount of total phenols found in the seeds and its antioxidant activity.

\section{Conclusion}

The study showed that watermelon seeds are rich source of fibre and minerals that are essential in the body system. The seeds from Crimson sweet promises to be a richer source of phenols and possess the highest antioxidant activity as compared to seeds from black diamond and charleston gray varieties. These watermelon seeds may provide considerable medicinal, health and economic benefits if freshly consumed or utilized in food products.

\section{References}

[1] Ministry of Food and Agriculture (2011). Facts sheet on watermelon production. Ghana.

[2] Okonmah, L. U., Agbogidi, O. M. and Nwagu, O. K. (2011) Evaluation of four varieties of watermelon (critrullus lanatus thumb) in Asaba agro-ecological environment. International Journal of Advanced Biological Research. 1(1), 126-130.

[3] Oyeleke, G. O. 1, Olagunju, E.O. and Ojo, A: (2012) Functional and Physicochemical Properties of Watermelon (Citrullus Lanatus) Seed and Seed-Oil. Journal of Applied Chemistry, 2(2), 29-31.

[4] Braide W., Odiong, I. J. and Oranusi S. (2012) Phytochemical and Antibacterial properties of the seed of watermelon (Citrullus lanatus). Prime Journal of Microbiology Research, 2(3), 99-104.

[5] Jensen B. D., Toure, F. M., Hamattal, M. A., Toure, F. A. and Nantoumé D. A. (2011). Wtermelons in the Sand of Sahara: Cultivation and use of indigenous landraces in the Tombouctou Region of Mali, Ethnobotany Research and Applications, 9, 151-162.

[6] Trease, G. E. and Evans, W. C. (2002). A text book of pharmacognosy, $15^{\text {th }}$ edition. Academic press, London.

[7] Tiwari, P., Kumar, B., Kaur, M., Kaur, G. and Kaur, H. 2011. Phytochemical screening and Extraction: A Review. Internationale Pharmaceuticasciencia 1 (1), 98-106.

[8] Boakye, A. A., Wireko-Manu, F. D., Agbenorhevi, J. K. and Oduro, I. (2015) Antioxidant Activity, Total Phenols and Phytochemical Constituents of four Underutilised Tropical Fruits, International Food Research Journal, 22(1), 262-26. 
[9] Dossou, V. M. Agbenorhevi, J. K., Combey, S. and Afi-Koryoe, S., (2014) Ackee (Blighia sapida) Fruit Arils: Nutritional, Phytochemicals and Antioxidant Properties, International Journal of Nutrition and Food Sciences, 3(6), 534-537.

[10] Agbenorhevi, J. K. and Marshall L. J. (2012) Investigation into the total phenols and antioxidant activity during storage of fruit smoothies. Journal of Food Science and Engineering, 2, 72-79.

[11] Lakshmi, J. and Purnima K. (2011). Nutritional potential, bioaccessibility of minerals and functionality of watermelon (Citrullus vulgaris) seeds. LWT - Food Science and Technology, 44, 1821- 1826.

[12] FAO (1982), Food composition table for the near East nuts and seeds, FAO Food and Nutrition Paper 26.

[13] Madaan, T. R. and Lai, B. M. (1984). Some studies on the chemicalcomposition of Cucurbit kernels and their seed coats. Plant Foods for Human Nutrition, 34: 81-86.

[14] Loukou A. L., Gnakri D., Dje Y., Kippre A. V., Malice M., Baudoin J. P., Zoro Bi I.A. (2007) Macronutrient Composition of Three Cucurbit Species Cultivated for Seed Consumption in Cote D'lvoire. African Journal of Biotechnolology, 6 (5), 529-533.

[15] Mabalaha, M. B., Y. C. Mitei and S. O. Yoboah, (2007) A Comparative study of the properties of selected melon seeds oils as potential candidates for development into commercial edible vegetable oil. Journal of American Oil Chemists 'Society, 84: $31-34$

[16] Hassan, L. G., Dangoggo, S. M. Umar, K. J. Saidu, I. and Folorunsho, F. A. (2008). Proximate, Minerals and Anti-nutritional Factors of Daniellia oliveri seed kernel. Chemclass Journal, 5, 31-36.

[17] Özcan M., (2009). Some Proximate Characteristics of Fruit and Oil of Walnut (Juglansregia L.) Growing in Turkey, Iranian Journal of Chemistry \& Chemical Engineering, 28(1), 57-62.

[18] Jack T. J. (1972). Cucurbit Seeds: Characterizations and Uses of Oils and Proteins. A Review. Economic Botany 26(2): 135141.

[19] Wilcox, B. F. (2006). Fundamentals of Food Chemistry. $1^{\text {st }}$ Edition, Paraclete, Nigeria, pp 124-16.

[20] Ojieh G. C., Oluba O. M., Ogunlowo Y. R., Adebisi K. E., Eidangbe G. O. and Orole R.T. (2008). Compositional studies of Citrulluslanatus (Egusii melon) Seed. The Internet Journal of Nutrition and Wellness. Vol. 6 No 1.

[21] Acar, R., Özcan, M. M., Kanbur, G. and Dursun, N. (2012). Some physic-chemical properties of edible and forage watermelon seeds, Iran. J. Chem. Chem. Eng., 31(4), 41-47.

[22] Oseni, O. A and Okoye, V. I.: (2013) Studies of Phytochemical and Antioxidant properties of the Fruit of Watermelon
(Citrullus lanatus). Journal of Pharmaceutical and Biomedical sciences; 27(27): 508-514. (Article no 14).

[23] Samia F. El-Safy, Rabab, H. Salem and Abd El-Ghany, M.E. (2012): Chemical and Nutritional Evaluation of Different Seed Flours as Novel Sources of Protein, World Journal of Dairy \& Food Sciences , 7 (1),: 59-65, 2012.

[24] Arapitsas P.: (2012) Hydrolyzable tannin analysis in food. Elsevier Food Chemistry. Food Chemistry 135 1708-1717.

[25] Abdul-Mumeen I.: (2013). Biochemical and Microbiological analysis of shea nut cake: A waste product from shea butter processing. MPhil. Thesis, Kwame Nkrumah University of Science and Technology.

[26] Varadharajan V., Janarthanan U. K., Vijayalakshmi K. (2012) Physicochemical, Phytochemical screening and Profiling of secondary metabolites of annona squamosa leaf extract. World Journal of pharmaceutical research. 1(4), 1143-1164.

[27] Tiwari P., Kumar B., Kaur M, Kaur G and Kaur H. (2011) Phytochemical Screening and Extraction Review. Internationale Pharmaceutica Sciencia. 1(1), 98-106.

[28] Oseni, O. A. and Okoye, V. I.: (2013) Studies of Phytochemical and Antioxidant properties of the Fruit of Watermelon (Citrullus lanatus). Journal of pharmaceutical and biomedical sciences; 27(27): 508-514.

[29] Francisco, I. A. and Pinotti M. H. P.: (2000) Cynogenic glycosides in plants. Brazilian Archives of Biology and Technology, 43(5). 487-492.

[30] Johnson J. T., Iwang E. U., Hemen J. T., Odey M. O., Efiong E.E. and Eteng, O. E.: (2013) Evaluation of anti-nutrient contents of watermelon Citrullus lanatus. Annals of Biological Research, 3 (11): 5145-5150.

[31] Joshi, H. and Jain, P. K. (2012) Coumarin: Chemical and Pharmacological Profile. Journal of Applied Pharmaceutical Science 2(6), 236-240.

[32] Rahman H., Manjulak K., Anoosha T., Nagaveni K., Chinna E.M. and Dipankar B.: (2013) In-vitro antioxidant activity of citrullus lanatus seed extracts. Asian Journal of Pharmaceutical and Clinical Research. 6(3), 152-157.

[33] Duda-Chodak A. and Tarko T. (2007) Antioxidant properties of different fruit seeds and peels. Acta Scientiarum Polonorum 6(3), 29-36.

[34] Mohammed I. S. A., Motaal A. A. and Ludger B. (2011) Total Phenolic Content and Antioxidant Activity of Standardized Extracts from Leaves and Cell Cultures of Three Callistemon Species. American Journal of Plant Sciences, 2, 847850.

[35] Rodriguez E. B., Flavier, M. E., Rodriguez-Amaya D. B. and Amaya-Farfan J. (2006) Phytochemicals and functional foods. Current situation and prospect for developing countries. Segurança Alimentar e Nutricional, Campinas, 13(1): 1-22. 